\title{
The Diversity and Composition of Woody Plants in Chebera Churcura National Park (CCNP), Southern Ethiopia
}

\author{
Mezmir Girma $^{1}$, Melesse Maryo $^{2}$ \\ ${ }^{1}$ Shashemene Botanical Garden, Ethiopian Biodiversity Institute (EBI), Shashemene, Ethiopia \\ ${ }^{2}$ Dilla University, Department of Biology (DU), Dilla, Ethiopia \\ Email: mezemirg@gmail.com, Melessedevid@gmail.com
}

How to cite this paper: Girma, M., \& Maryo, M. (2018). The Diversity and Composition of Woody Plants in Chebera Churcura National Park (CCNP), Southern Ethiopia. Open Journal of Forestry, 8, 439-458. https://doi.org/10.4236/ojf.2018.84028

Received: January 2, 2018

Accepted: August 18, 2018

Published: August 21, 2018

Copyright $\odot 2018$ by authors and Scientific Research Publishing Inc. This work is licensed under the Creative Commons Attribution International License (CC BY 4.0).

http://creativecommons.org/licenses/by/4.0/ (c) (i) Open Access

\begin{abstract}
National parks harbor the most valuable biological diversities of national and global significance. The study of these diversities assists for the proper resource management. This study was carried out to determine woody species diversity and composition in CCNP. Systematic sampling was used to collect vegetation data from 67 plots ( $400 \mathrm{~m}^{2}$ each), which were laid following altitudinal gradient. From each plot presence/absence of woody species, abundance and structural data were recorded. R Program, Sorensen's similarity, Shannon diversity index were used for vegetation analysis. Our result indicated that a total of 106 plant specimens belonging to 42 families and 90 genera were identified, of which $57.6 \%$ were trees, followed by $18.8 \%$ shrubs, $7.6 \%$ liana and $16 \%$ tree/shrub. The three most dominant families were Fabaceae, Rubiaceae and Combretaceae. Five vegetation community types were identified. Millettia ferugenia-Vepris danelii, and, Combrutum molle-Terminalia browni are among others. The tree density and basal area were 426.5 trees/hectare and $30.92 \mathrm{~m}^{2} /$ hectare, respectively. The diversity and evenness indices were 3.88 and 0.46 for the study area, respectively. CCNP has more similarity with Bonga and Yayu afromontane forests of Ethiopia. Disturbances caused by the human activities and wild animals such as elephant were major threats to plant biodiversity in CCNP. We recommend floristic as well as ethnobotanical investigations to realize fully the existing plant diversity and their importance. Moreover, national attention should be given to ensure sustainable use of CCNP with its incredible biological resources.
\end{abstract}

\section{Keywords}

Diversity, National Park, Population Structure, Plant Community 


\section{Introduction}

Ethiopia is endowed with diverse vegetation types due to its extraordinary number of ecological zones, which range from high altitude Afro-alpine vegetation in the central high lands to arid low-lands in the east, and rain forests in the west (Friis et al., 2010) that in turn host rare and endangered species and high rates of endemism both in floral and faunal diversities. According to (Gebre-Egziabher, 1991), the number of species of higher plants ranges between $6500-7000$, of which $10 \%-12 \%$ are endemic to Ethiopia. High concentrations of endemic species and great human land-use pressure therefore, make internationally recognized as the Eastern montane Biodiversity Hotspot (Schmitt et al., 2010). Forests have immense economic importance, which can provide variety of products especially for rural people, in the form of food, fodder, fuel, medicine, timber, resins, and oil, etc. (Naveed et al., 2012).

Forests are also ecologically important in providing habitat for wildlife, influencing climate and maintaining global balances of carbon and atmospheric pollutants. They regulate Climatic factors of a given area. They also protect the soil and landscape from wind and rain erosion. However, due to intricate factors such as anthropogenic, climatic and natural factors, forest plant diversity is facing threats, which may include deforestation, forest fire, land degradation, overexploitation, overgrazing, shifting cultivation, habitat loss and invasive species (Environmental Protection Authority of Ethiopia, 2011). Sixty seven houses holds at "Yilga-buba" and 11 households in "Adabacho" kebeles settled and clearing forest for agriculture. Expansion of agriculture towards the park in bordering kebeles such as in "Keribela" and "Chawda" is a threat to the National park as well as to the nearby state forest reserves.

The study area is located in the south west part of the country where most of the remaining moist montane forest is found (Yeshitla \& Bekele, 2002). Even though, the study area is home for diverse plant and animal communities. It is currently threatened by human activities for the expansion of agriculture. Therefore the park management should take appropriate measures to protect the forest resources. CCNP have become regionally gazetted at the status of National Park with the main objectives of Protection and conservation of the biological resources together with the development of tourism in the area (Appendix).

Understanding the type of species, their distribution, and relative degree of abundance of each species is very important before the commencement of any serious of detailed work in the area (Zewdie, 2007). Ecological status of a particular region is determined by assessing its biodiversity, prevailing conditions of the environment and their interactions with the species. Understanding species diversity and distribution patterns is important to evaluate the complexity and resources of the forests (Kumar et al., 2006). The availability of truthful data on forest resources is avital requirement for management and planning within the context of sustainable development. Knowledge of floristic composition and 
structure of forest resources is very important to protect threatened and economic species (Ssegawa \& Nkuutu, 2006). The absence of any previous botanical studies in CCNP is a bottleneck to prepare management plan for the national park currently. Without scientific information on the floral communities in the park, and their relation to the wild animals, the management of the park will be severely handicapped. Therefore, ecological study of the park's plant biodiversity is the basis for meaningful planning to rationalize the use of resources in side CCNP. Thus the purpose of this study is mainly to make assessment on the woody species diversity so that determine the plant community of the park, and the associated management challenges of the CCNP.

\section{Materials and Methods}

\subsection{The Study Area}

CCNP is found with in western side of the central Omo Gibe basin in between Dawro zone and Konta special wereda-of SNNPRS in Ethiopia. The park is located in the south western natural forest belt of the country. The forest in the south west part of the country is characterized by secondary forest types of moist evergreen montane forests within altitudinal range of 1100 - 2700 m.a.s.l. The annual rainfall varies between $1200 \mathrm{~mm}$ and over $2000 \mathrm{~mm}$ (Mengistu, 2002). Bench Maji, Sheka zones, Konta special woreda, and partly Dawuro zone are areas where patches of forests are found. The study area is reached after a drive of $420 \mathrm{~km} \& 460 \mathrm{kms}$ to the south west of Hawassa and Addis Ababa, respectively. It is also reached after a drive of $120 \mathrm{~km}$ from Jima town to the east. It covers an area of $1190 \mathrm{~km}^{2}$. Its geographical range lies between an altitude from 900 m.a.s.l at Churchura and to 2450 m.a.s.l. at Gudumu in Dawro zone. Geographically it is located between $35^{\circ} 55^{\prime} 00^{\prime \prime}$ and $36^{\circ} 57^{\prime} 17^{\prime \prime}$ latitude and $6^{\circ} 56^{\prime} 05^{\prime \prime}$ and $70^{\circ} 8^{\prime} 02^{\prime \prime} \mathrm{N}$ longitude (Figure 1) Three woredas and 14kebeles are bordering CCNP, (CCNP report, 2010).

The human population in Dawro Zone was estimated to be 102,621 and in Konta special woreda was 90,513. Totally 16 kebeles are bordering CCNP. Out of this the population in bordering "kebeles" to CCNP from Isera and Tocha woredas of Dawro Zone and Konta special woreda was estimated to be 22,532 and 16,948 , respectively.

The average size of land per household is 2 - 3 hectares, which includes living compounds. The major livelihood occupation around the study area is mixed agriculture, growing mainly enset around home-steads and crops like maize, wheat, Teff, and sorghum. Non timber forest products (NTFP) such as wild coffee, honey, medicinal herbs, and spices are collected from the forest. The local people are also involved in game hunting and fishing in the rivers for subsistence use (Ademasu, 2006).

There are two traditional climatic zones in the study area, namely Kola' (Lowland) climatic zone with the temperature ranging from $21^{\circ} \mathrm{C}-27.5^{\circ} \mathrm{C}$ where as 


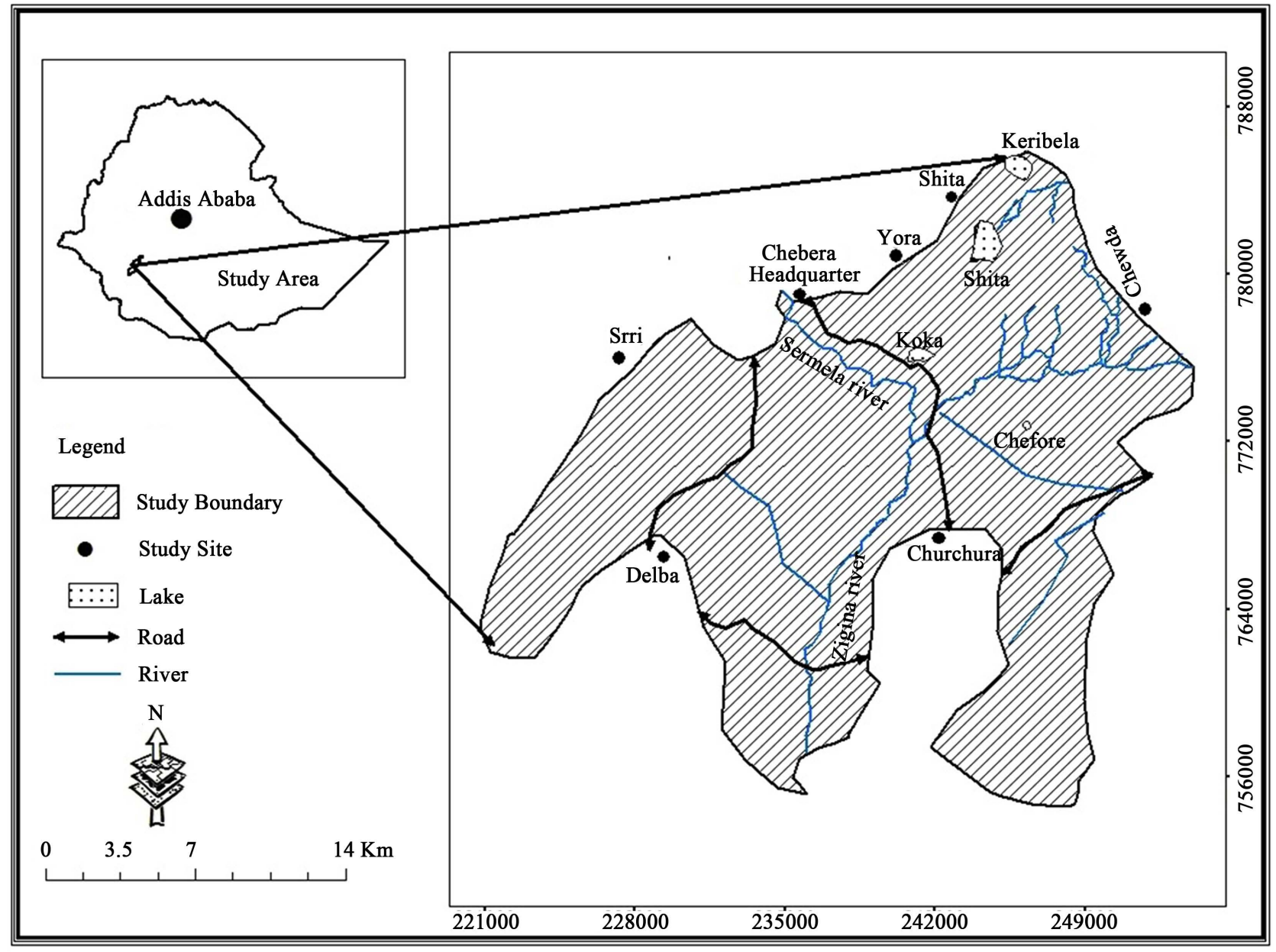

Figure 1. Location of Chebera Churchra national park. Source: (Datiko \& Bekele, 2013).

Weynadega (Mid-altitude) climatic zone with temperature ranging between $11^{\circ} \mathrm{C}$ and $16^{\circ} \mathrm{C}$. The rainfall is unimodal type that rains from March through September with the peak in July. December, January and February are the dry season of the year. The hottest months are January and February while, the coldest months are July and August with the mean minimum and maximum temperature of $12^{\circ} \mathrm{C}$ and $28^{\circ} \mathrm{C}$, respectively.

According to (Friis, 1992), there are three forest types characterize Southwestern Ethiopia, namely: Low land dry peripheral semi evergreen Guineo-Congolean forest that extends from 450 to $600 \mathrm{~m}$; Afromontane rainforest that extends from 1500 to $2600 \mathrm{~m}$ a.s.l, and Transitional afromontane rainforest type that extends from 500 to $1500 \mathrm{~m}$ a.s.l.

Eastern Africa countries are well known for their biodiversity resources which offer some of the world's well known wild life destinations. CCNP provide refuges to 37 larger mammals including (Elephant, Buffalo, lion, leopard), 137 avian species of which 5 are endemic to Ethiopia. It also harbors different attractions like Crater lakes, landscapes covered with the secondary montane forest and woodland shrub-land vegetation (CCNP, 2010). Wildlife Parks are major 
destinations to domestic and international tourists, which can generate considerable amount of income to the country. Tourism can be effective tool in conservation and sustainable use of biological diversities.

\subsection{Sampling Procedure and Design}

Reconnaissance survey had been conducted for one week prior to the actual field work. Short training was given to park experts and scouts by the researcher to familiarize the data collection work and to develop their skill. Systematic sampling design was used to collect data on vegetation and environmental variables. Vegetation data was collected from sample plots placed on systematically laid transect lines. The co-ordinates were determined using Garmin GPS 45XL. Plots of $20 \mathrm{~m} \times 20 \mathrm{~m}\left(400 \mathrm{~m}^{2}\right)$ were laid at every 150 meters on mountain slopes where vegetation change is assumed to be more liable. A total of 67 plots were laid along 18 transect lines. The first sample plot was chosen randomly and started 50 meters inward from the edge of the forest to avoid "edge effect". Transect plots method was employed in the studies of floristic composition by different researchers (Christine et al., 2010). Tree height and diameter inside the plot area were measured by sun to hypsometer and tape meter. The basal area (BA) was calculated for each tree/species from DBH (Diameter at Breast Height) using a formula $\mathrm{BA}=\pi(\mathrm{d} / 2)^{2}$.

\subsection{Data Collection}

Every woody stem including lianas with $\mathrm{DBH} \geq 2.5 \mathrm{~cm}$, and height $\geq 5 \mathrm{~m}$ in the sample quadrant were measured. Abundance and frequency of all trees, shrubs and lianas in the sample plots were calculated. The co-ordinates of each sample plot were determined using Garmin GPS. The DBH measurement was done with Meter tape. All the woody plants were recorded in the sample plots to be used in the analysis of structural features (density, diameter, and basal area) and the presence-absence data was taken.

Species were identified in the field level using field guide and personal expertise experience, the vernacular names mainly Konta and Dawro languages were considered for the recorded trees and shrubs. But those which are not identified at field level Voucher specimens were collected, pressed and taken to national Herbarium of Addis Ababa University for identification.

\subsection{Structural Data Collection}

Height of trees and shrubs greater or equal to $5 \mathrm{~m}$ were measured using hypsometer for taller trees and shrubs (Bongers et al., 1988). The Tree height was also classified into six classes $(5-10 \mathrm{~m}, 11-15 \mathrm{~m}, 16-20 \mathrm{~m}, 21-25 \mathrm{~m}, 25-30$ $\mathrm{m},>31 \mathrm{~m})$. Physiographic variables such as altitude, slope and aspect, were measured for each quadrate using, GPS, clinometer and sunto compass. Following, the level of anthropogenic impacts such as tree cutting and agricultural activities were evaluated by counting stumps, and by field observation inside the 
study area. In some parts especially in the high lands of the study area agriculture activities and tree cutting were scored $2-3$ (rate). Firing was common in savanna wood land areas. The level of firing disturbance was considered to normal level, because no indication of forest damage except for burnt grass. The state of human interference at each plot was estimated following (Yeshitla \& Bekele, 2002) and with modifications. A 0 - 3 subjective scale was taken into consideration to record presence or absence of stumps, logs and signs of fuel wood collection. Therefore, the magnitude of the impact was quantified as follows $0=$ nil; 1 = low; 2 = moderate; and 3 = heavy.

\section{Community Perception}

Heads-of-households were randomly selected for interview. 50 household heads from 5 rural kebeles were interviewed i.e., 8 to 10 households from each of the five kebeles. The survey included both closed and open-ended questions across three broad categories: 1) views towards wildlife and wildlife conservation 2) views towards protected area management and staff; and 3) a series of household demographic questions, including information about each household's source of Income and lively hood occupation. Furthermore, the perception of the local people on the National park/the protected area, were collected using both structured and semi-structured questionnaire.

\subsection{Data Analysis}

Species diversity is determined by means of species richness and species evenness. Species richness (S) is the oldest and most intuitive measure of biological diversity Magurran, (2004), which in the current study represents the total number of woody species of the park in this study. The Shannon-Wiener diversity index combines two quantifiable measures; the species richness and species equitability. $H^{\prime}$ is calculated using the formula,

$$
H^{\prime}=-\sum p_{i} \ln p_{i}
$$

where $p_{i}$ is the proportion of individuals of species " $\vec{i}$ " in the community. An additional measure of diversity is the measure of Evenness $(E)$ that is a measure of how similar the abundance of different species is. It is calculated as the ratio of observed diversity $(H)$ to maximum diversity $\left(H_{\max }\right)$ using the formula,

$$
E=H^{\prime} / H_{\max }=H^{\prime} / \ln S
$$

where $S=$ number of species, and $\ln$ is a natural log. E. Using Menhinick's index, known as, $D=s / \sqrt{N}$ where $s=$ richness, $N=$ the total number of individual stems.

Species similarity is an index of measure of the degree to which the species composition of quadrates or samples is a like; whereas dissimilarity coefficient assesses which two quadrates or samples that differ in composition. Sorenson is the most common binary similarity coefficients because it relies on presence or absence data. Sorenson's Coefficient is expressed as $S s=2 a /(2 a+b+c)$, (Kent \& Coker, 1992). Where $a=$ number of species with common to both quadrates; $b=$ 
number of species unique to Quadrate 1; and $c=$ number of species unique to quadrate 2 .

\section{Important value index (IVI)}

Moreover, from the structural data, frequency, density, basal area, and IVI were calculated. IVI = Relative density + Relative frequency + Relative Dominance (Kent \& Coker, 1992).

Multiple linear regressions were computed among all environmental variables using Minitab version 16 computer program. The difference in species composition and diversity among the communities was considered as a function of the environmental variables these environmental factors were used to associate the relationship between environment and vegetation distribution. The rate of human interference has been considered by assessing stumps. Floral Community and denedrogram were determined using R.2.4.1 computer soft ware (The R Core Team, 2012).

\section{Results and Discussions}

\subsection{Plant Species Diversity}

A total of 106 species of woody plants (shrubs, trees, and lianas) belonging to 90 genera and 42 families were identified from the CCNP forest. Trees occupied the highest floristic composition, which together with shrubs contributed to $75 \%$ of the floristic composition in CCNP forest. Of the total species examined six were endemic to Ethiopia. Millitia ferugenia (Hochst.) Bak. Vepris daneli (Pichi.-Serm.), Kokwaro, Solanecio gigas (Vatke) C. Jeffrey, Cussonia ostinii Chiov. Erythrina brucei Schweinf. and Rhus glutinosa. Millettia ferruginea is the most abundant species recorded 84 followed by Maesa lanceolata 80, Syzygium guineense 73 and Vepris danelii 62 during this study in CCNP.

The families with the highest species richness were Fabaceae represented by 29 species, followed by Rubiaceae ( 8 species), and Combrataceae ( 7 species). The three families contributed $29 \%$ of the total species. The studies made by (Alemu, 2011) and (Alelign et al., 2007) recorded 87 and 113 species from central and northern parts of Ethiopia. However, both indicated that Fabaceae had the highest number of taxa in the studies, which is consistence with our finding. This could show that the abundance, and the wide spread distribution of these families to different agroecological zones in the country.

The high species richness could be due to a wide range of ecological segments, including moist afromontane forest, riverine forest, and savanna wood land and shrub land. Moreover, the droppings of wild animals facilitate dispersion and germination of seeds through their gastrointestinal systems. Also as the study area is under the protected area system, it contributes significantly to its richness.

\subsection{Plant Community Types}

Five plant communities (Clusters) were identified at about 35\% dissimilarity lev- 
el from hierarchical cluster analysis/dendrogrmme/ (Figure 2). The abundance data of a species were used for the analysis. Plant community types were given names after two indicator species of high synoptic values calculated using Rprogram.

1) Millettia ferruginea-Vepris danelii type community.

This community is the largest of all in the number of species where there were 28 plots (41.8\%) (Table 1) and contains 61 species (57.5\%). It was found between the altitudinal ranges of 1950 - $2255 \mathrm{~m}$ a.s.l, and the slope gradient varied

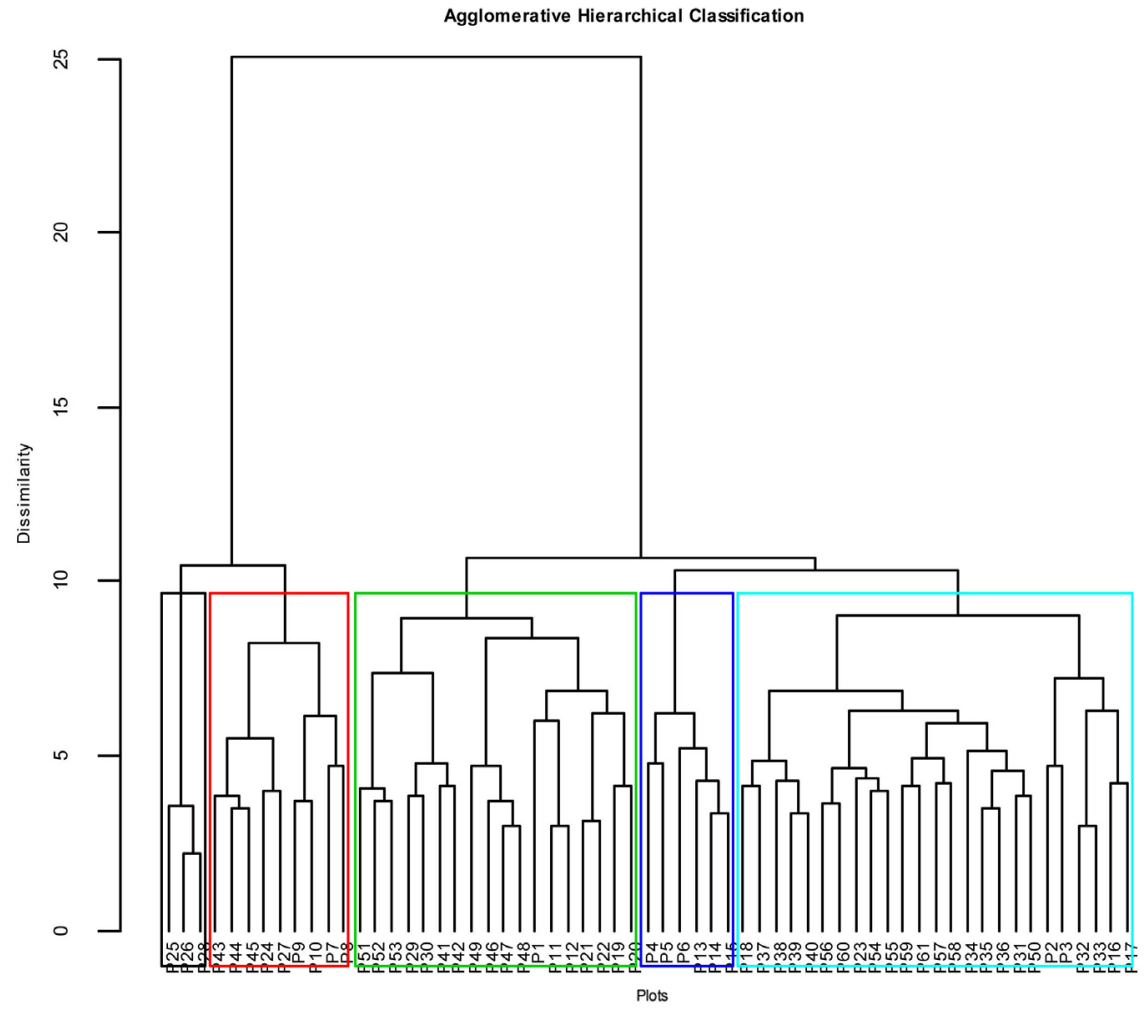

Figure 2. Dendrogramme for the forest of CCNP.

Table 1. Plant community types, sample plot number and their altitudinal location.

\begin{tabular}{|c|c|c|c|c|c|}
\hline Comm. & Community name & $\begin{array}{l}\text { Numer } \\
\text { of plots }\end{array}$ & $\begin{array}{l}\text { Numer } \\
\text { of species }\end{array}$ & Plots in the community & $\begin{array}{l}\text { Altitude } \\
\text { range }(\mathrm{m})\end{array}$ \\
\hline I & $\begin{array}{c}\text { Millettia ferruginea- } \\
\text { Vepris danelii }\end{array}$ & 28 & 61 & $\begin{array}{c}1,2,3,5,6,12,14,17 \\
24,25,26,27,28,29,31\end{array}$ & $1950-2255$ \\
\hline II & $\begin{array}{c}\text { Clerodenderum myriciodes- } \\
\text { Macranga capensis }\end{array}$ & 9 & 13 & $\begin{array}{c}4,13,15,18,9 \\
20,21,22,23\end{array}$ & $2000-2367$ \\
\hline III & $\begin{array}{c}\text { Croton macrostchyus- } \\
\text { Maesa lanceolata }\end{array}$ & 13 & 46 & $\begin{array}{c}16,39,42,43,45,46, \\
48,49,50,52,56,57,59\end{array}$ & $1643-2300$ \\
\hline IV & Ficus vasta-Cordia africana & 4 & 10 & $32,33,35,36$ & $1188-1207$ \\
\hline $\mathrm{V}$ & $\begin{array}{l}\text { Combretum molle- } \\
\text { Terminalia browni }\end{array}$ & 13 & 43 & $\begin{array}{l}7,8,9,10,11,30,37 \\
62,63,64,65,66,67\end{array}$ & $900-1207$ \\
\hline
\end{tabular}


from $15 \%-55 \%$. This community is a part of the main high land forest characterized by afromontane forest type. The most important species to this community are Syzygium guineense, Macaranga capensis, Vepris dainellii, Ilex mitis, Galinieria saxifrage among the tree species and Oxyanthus speciosus, Clausena anisata, and Vernonia ampla are among the shrub species. Olea welwitschii is an emergent tree species with $45 \mathrm{~m}$ in this community. The common climbers/lianas of this community were Hippocratea goetzei and Landolphia buchananii. A tree fern called Cyathea manniana (Figure 3) was found abundantly in the community at an altitude of 2430 m.a.s.l.

Generally, this community is characterized by relatively high level of anthropogenic disturbance, mainly tree felling (deforestation). This is because the optimal climate in the mid altitude, plant diversity, density and richness are observed to be higher in this community and also the area is assumed to be more suitable for human settlement. From the slope data the physiography of the area is characterized by rolling to hilly topography.

2) Clerodenderum Myriciodes-Macranga-Capensis Type Community

It consists of nine plots (11.9\%) and 13 species (12.3\%) (Table 1). Some of the trees recorded in this community are Macaranga capensis, Syzigium guanines, Clerodenderum myriciodes, Dombeya schimperi, Rytigynia neglecta, Schefflera abysinica, Ilex mitis, prunus africanum, Vepris danelii, Galineria saxifraga, and Coffea arabica is the shrub species while Afromomum kororima and Piper capense are some of the economically important spice herbs recorded in this community. This community is located between the altitude ranges of 2000 and $2367 \mathrm{~m}$ a.s.l. where the slope gradient ranges from $20 \%-45 \%$. Moreover, the "Nerpi hill" which is used as a vantage point and floristically an important site is

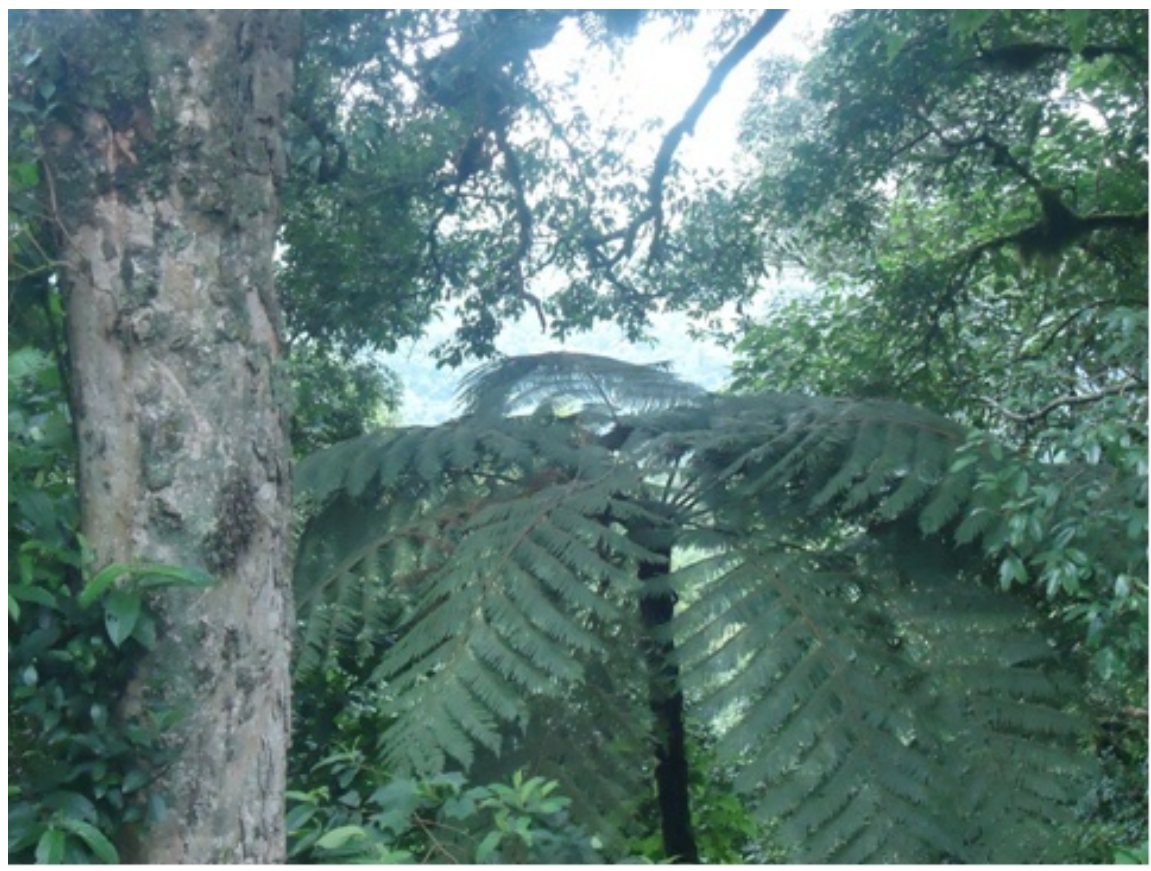

Figure 3. Cyathea manniana. 
found in this community. Where half part of the hill is dominated by only two tree species 30\% by Macaranga capensis and 70\% by Syzygium guineense. The other half is covered by different types of species. The $S$. guineense trees recorded on the hill are young trees with DBH ranging from $15-19 \mathrm{~cm}$. Thus, no saplings of M. capensis and/or S. guanines were observed instead Polyscias fulva and Maesa lanceolata saplings dominate the community. This is may be due to either the wild animals such as Baboons and Colubus monkey which were observed in the area feeding on the fruits, have removed the germinating seeds, or blown away by wind or by some other factors. The saplings observed in the area and the next generation that invades the hill may be M. lanciolata and P. fulva. (Figure 4).

This community is characterized by highest altitude, steep slope, and mountainous topography. Because of the high settlements in the high land areas human induced disturbance in the form of deforestation is found to be the highest, leaching of soil minerals at the steep slopes and as a result, the woody plant richness and density became minimal.

3) Croton Macrostachyus-Maesa Lanceolata Community Type

This community consisted of 13 plots (19.4\%) and 46 plant species (43.4\%) (Table 1), and was found between the altitudinal range of $1643-2300 \mathrm{~m}$ a.s.l. The slope gradient varied between $20 \%-60 \%$. The most important species of this community include Millettia ferruginea, Croton macrostachus, Maesa lanciolata, Macaranga capensis, Polyscias fulva, Rothmania urcelliformis, and Galineria saxifraga. While Verononia ampla, Maytenus arbutifolia, Brucea anti-dysentrica and Schrebera alata are the main shrub species identified in this community. The steep slopy landscape of this community made it less accessibile to human induced disturbance such as deforestation. However, due to higher run off and minerals leaching, both density and richness seems to decrease at higher slopes greater than $30 \%$ when compared to others. Figure 5 shows that species richness and slope are highly correlated. In general because of optimum environmental factors the species richness is high at the intermediate slope (Figure 5). A study showed that the slope influences the distribution of individual plants and communities by indirectly regulating the distribution of moisture, nutrients and through the influence of micro-climatic conditions in the site (Parker \& Bendix, 1996).

This community hosted some rare tree species such as Warburgia ugandensis, which has not been reported in other places except Harena forest in Ethiopia. Rhus ruspoli, which is normally a shrub in most areas, is now grown up to the size of $35 \mathrm{~cm}$ in DBH. And also 50 ha shrub land was found in this community which had not been reported by the park until this study. Hippocratea africana, Rhamnus prinoides and Embalaa scimperiana are some of the recorded climber species in this community. Spices such as Aframomum corrorima, Zingiber officinale and Piper capense were well populated in this community.

4) Ficus Vasta-Cordia africana Community Type

This community is found between $1188-1207 \mathrm{~m}$ a.s.l. and the mean altitude 


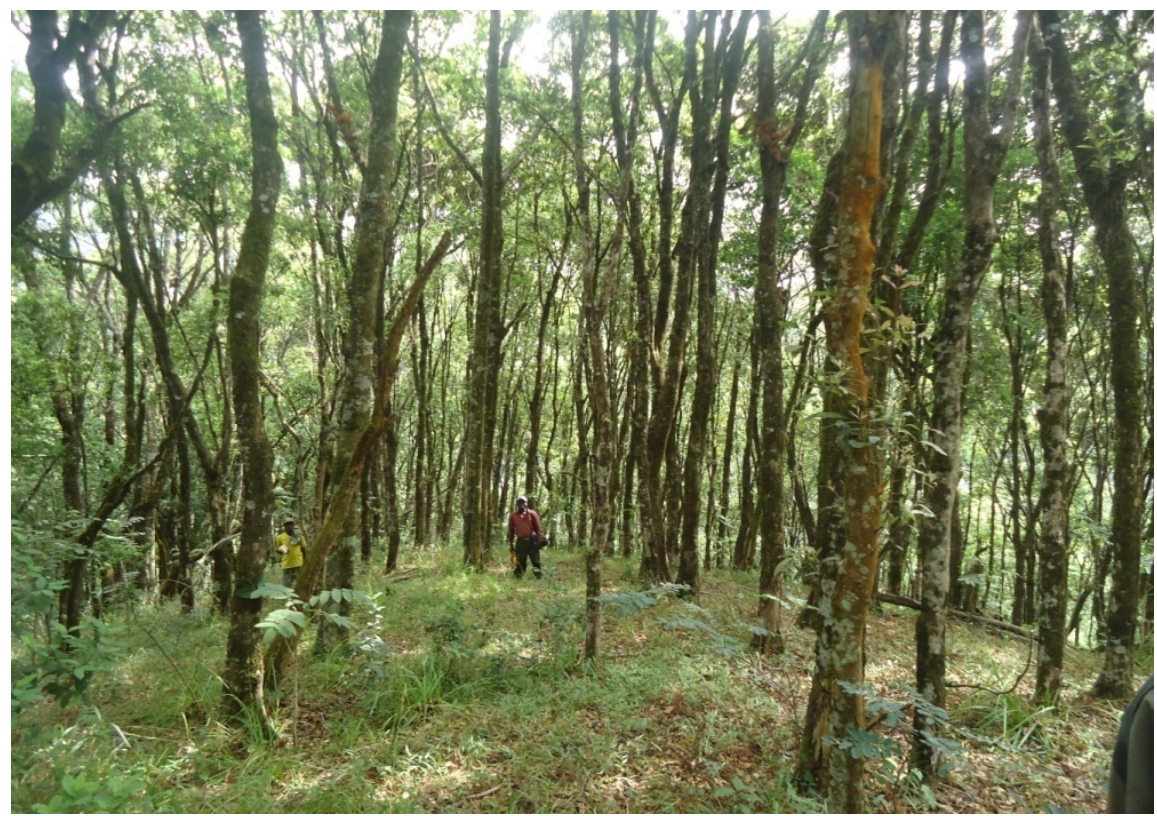

Figure 4. Nerpihill. dominated by only $M$. lanciolata and $P$. fulva saplings.

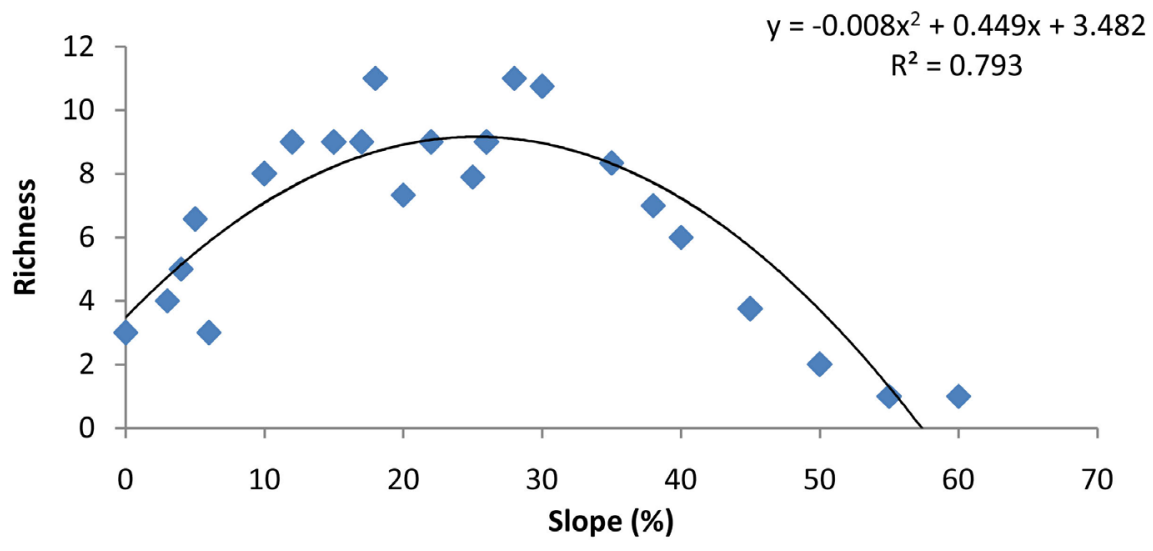

Figure 5. The species richness versus slope.

for this community is $1197 \mathrm{~m}$. It is the smallest of all communities which consists of only 4 plot (6\%) and 10 species (9.4\%) (Table 1). The physiography of this community is characterized by gentle slope varies between $3 \%-6 \%$. The trees were found scattered. The important species of the community are Ficus vasta, Cordia africana, phoenix reclinata, Combretum paniculatum, Ficus exasperate, Sapium ellepticum, Maytenus arbutifolia and Bridelia micrantha, among which Ficus vasta and Cordia africana were more abundant than others while Ficus exasperate a single tree species recorded in the study area. The common shrub of this community is Vernonia ampla. This community is characterized by lower altitude, gentle slope, and mainly a riverine forest type found along "Shoshima" river it is a suitable habitat for wild animals such as: African elephant, Buffalo and Giant forest hog. Because of their feeding habit, trampling and damaging impacts, big mammals caused disturbances and hence, plant density and richness are recorded in this community is very minimum; the average density 
per plot is 5.5. This is due to the fact that the maximum disturbance caused by heavily browsing and trampling impact of the African Elephant/Loxodenta africana/, which is known as robust and wasteful feeders that spends much of its time (about 66\%) in this community. They browse items that include bark, fruits, leaves, stems, flowers and fruits (Biru \& Bekele, 2012), and also uproot some trees (Figure 6) and feed on their roots of some species such as Gardenia lutia.This calls for strong commitment in the conservation of Gardenia lutia and should be addressed in the management plan of CCNP.

5) Combretum molle-Terminalia Browni Type Community

It is a savanna woodland community characterized by gentle slope mainly $3 \%$ - $10 \%$ and the under growth is mainly grass. The mean density and richness per plot recorded in this community is 14.6 and 8.7 , respectively. It is comprising 13 plots (19.4\%) but has 43 species (40.5\%) (Table 1). It is found mainly in the lower altitude of the study area between 900 - $1207 \mathrm{~m}$ a.s.l. The most important species in the upper canopy of this community are Terminalia browni, Combrutem molle, Stereospermum kunthinaum, Erythrina abyssinica, and Piliostigma thonningii while Gardenia lutia is the most abundant shrub. Tall savanna grass is the main ground level vegetation found in this community. Because Gardenia lutia is heavily browsed by elephants it is not found in community 4where elephants reside. But in community 5 where elephants rarely range the plant is found with high population (11.5\%).

Because of water scarcity and "malariya" suseptability this community is less favorable to human settlement. Due to this fact anthropogenic impacts are less and hence, plant diversity and species richness is getting high.

\subsection{Species Diversity, Richness and Evenness}

The calculated diversity index and evenness values were 3.89 and 0.46 , respectively for the study area. Species richness is a measure of the number of species found in a study area. The overall diversity index and evenness of woody species reported from "Zegie" are 3.72 and 0.84, respectively (Alelign et al., 2007). The

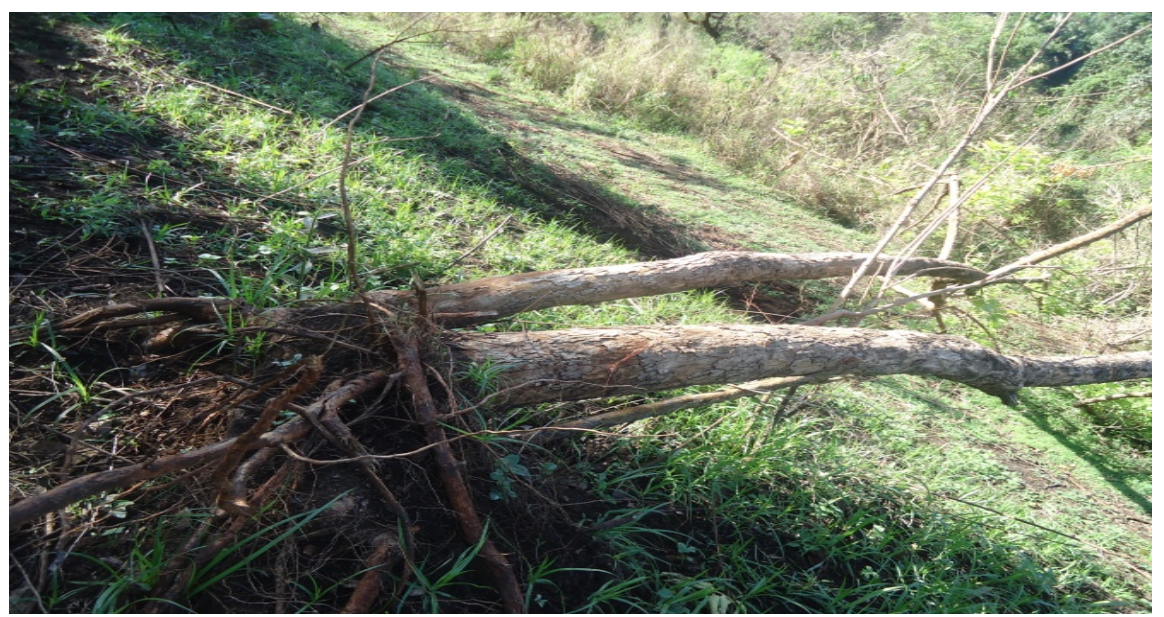

Figure 6. Disturbance caused by elephant. 
values usually fall between 1.5 and 3.5 only rarely surpass 4.5 (Biru \& Bekele, 2012). This indicates that the study area has the highest species diversity similarly to "Zegie" but unlike Zegie the species were unevenly distributed in the study area. Table 2 indicates that Community 1 had the highest species richness with the highest evenness values. Evenness is simply a measure of how similar species are in their abundances (Magurran, 2004). Regarding the species richness community 1,3 and 5 are almost equal where community 3 (8.8) followed by community 1 and 5 (8.7 each). The Shannon-Weiner diversity index ( $\left.\mathrm{H}^{\prime}\right)$ varied between 1.93 for Community 4, and 3.4 for communityl. Community 1 is the most diversified with a diversity index of 3.4 and a species evenness index (J) of 0.84 . All the communities have high eveness value though community 1,4 and 5 have similar evenness with higher values. Community with high evenness index is characterized by large number of species which are distributed equally in most sample plots. Community with high evenness index is more stable than the lesser ones.

\subsection{Environmental Factors versus Species Richness and Density}

The correlation out puts (Table 3 ) indicates significant relationship between altitude and stump. Anthropogenic impacts were evaluated by rating counted stumps in each plot. High number of stumps (2.8 - 4 stumps/plot) was counted in community 1 and 2 (Figure 7), which were very close to villages. The box plot indicates that disturbance level is the highest in community 2 followed by community 1 . But the stump count was found to be $(0-0.2 /$ plot $)$ at lower altitudes where human settlement is low in around community 4 and 5 (Table 3 ).

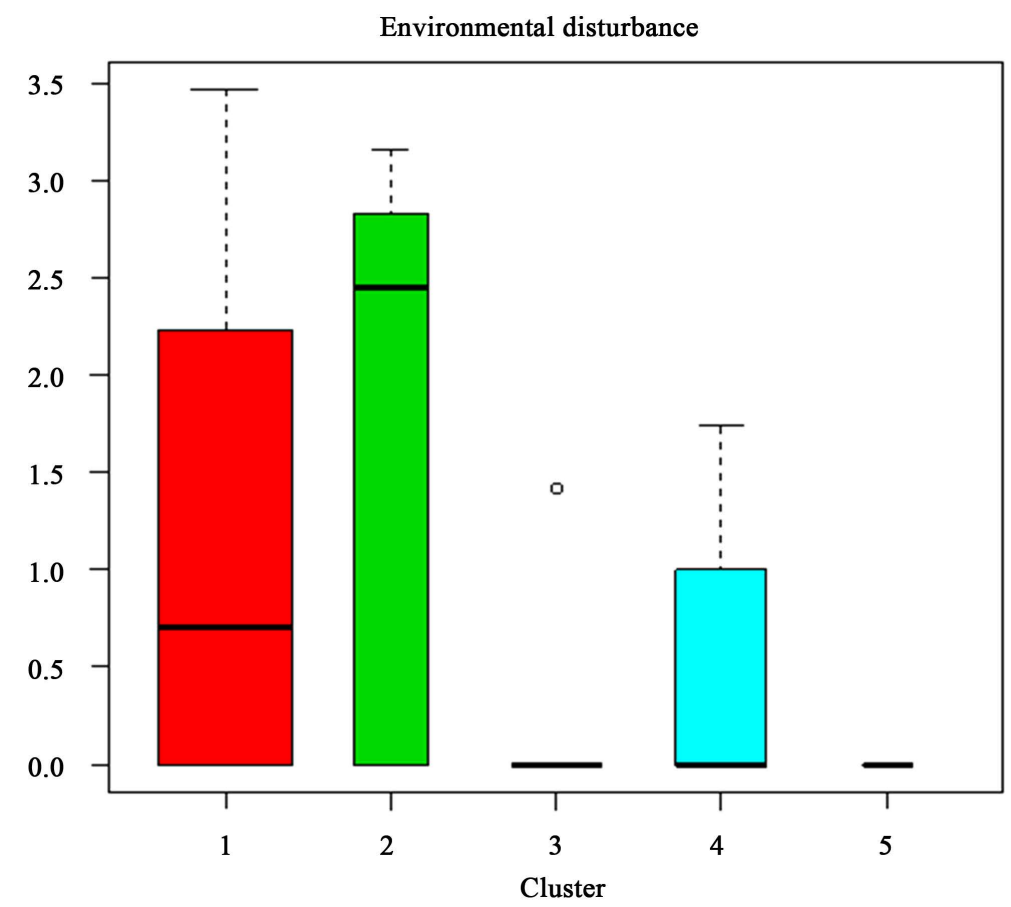

Figure 7. Box plot for disturbances versus community. 
Table 2. Species richness, evenness and Shannon Weiner diversity index of the plant community.

\begin{tabular}{cccccc}
\hline Community & Richness & $\begin{array}{r}\text { Diversity } \\
\text { index (H') }\end{array}$ & H' Max & Evenness (J) & Abundance \\
\hline 1 & 61 & 3.419 & 4.0943 & 0.84 & 487 \\
2 & 13 & 1.957 & 2.5649 & 0.76 & 62 \\
3 & 46 & 3.013 & 3.8286 & 0.79 & 347 \\
4 & 10 & 1.927 & 2.3026 & 0.84 & 26 \\
5 & 43 & 3.151 & 3.7612 & 0.84 & 174 \\
\hline
\end{tabular}

Table 3. Differences among the communities with respect to some environmental and structural parameters.

\begin{tabular}{|c|c|c|c|c|c|c|c|c|c|c|c|c|}
\hline \multirow[t]{2}{*}{ Community } & \multicolumn{2}{|c|}{$\begin{array}{c}\text { Altitude } \\
\text { (masl) }\end{array}$} & \multicolumn{2}{|c|}{$\begin{array}{l}\text { Aspect } \\
\text { value }\end{array}$} & \multicolumn{2}{|c|}{ Slope (\%) } & \multicolumn{2}{|c|}{$\begin{array}{l}\text { Disturbance } \\
\text { (no of } \\
\text { stumps/plot) }\end{array}$} & \multicolumn{2}{|c|}{$\begin{array}{l}\text { Richness } \\
\text { (no. of } \\
\text { spp/plot) }\end{array}$} & \multicolumn{2}{|c|}{$\begin{array}{c}\text { Density } \\
\text { (no of stems/plot) }\end{array}$} \\
\hline & Mean & SE & Mean & $\mathrm{SE}$ & Mean & SE & Mean & SE & Mean & SE & Mean & SE \\
\hline 1 & $1827.2^{\mathrm{b}}$ & 61.06 & 2 & 0.2 & $25.2^{\mathrm{b}}$ & 2.6 & $2.8^{\mathrm{b}}$ & 0.72 & $8.7^{\mathrm{b}}$ & 0.61 & $17.9^{\mathrm{bc}}$ & 1.74 \\
\hline 2 & $2252.2^{c}$ & 52.89 & 2 & 0.4 & $32.2^{\mathrm{b}}$ & 3.7 & $4.7^{\mathrm{b}}$ & 1.34 & $3.9^{\mathrm{a}}$ & 0.7 & $11.9^{\mathrm{b}}$ & 2.55 \\
\hline 3 & $1978.5^{\mathrm{b}}$ & 66.49 & 2.5 & 0.3 & $33.8^{\mathrm{b}}$ & 3.8 & $0.6^{\mathrm{a}}$ & 0.27 & $8.8^{\mathrm{b}}$ & 0.82 & $25.2^{c}$ & 2.97 \\
\hline 4 & $1197.2^{\mathrm{a}}$ & 4.59 & 2.2 & 0.6 & $4.5^{\mathrm{a}}$ & 0.7 & $0^{\mathrm{a}}$ & 0 & $4^{\mathrm{a}}$ & 0.91 & $5.5^{\mathrm{a}}$ & 0.5 \\
\hline 5 & $1075.7^{\mathrm{a}}$ & 28.06 & 1.5 & 0.3 & $4.5^{\mathrm{a}}$ & 1 & $0.2^{\mathrm{a}}$ & 0.15 & $8.7^{\mathrm{b}}$ & 0.61 & $14.6^{\mathrm{b}}$ & 1.96 \\
\hline
\end{tabular}

Forests are encroached for fuel wood and construction purpose by the nearby dwellers. In some kebeles such as "Keribela", "Yilgabuba" and "Chawda" deforestation for the expansion of agriculture towards the study site was observed; which could be a potential threats to the protected area.thus it should be considered in the management plan the park.

\subsection{Phytogeographical Comparison}

Phytogeographical analysis is one of the attractive aspects in the study of botany. The analysis gives information on the similarities of floral composition in different areas. The afromontane areas also vary in floristic composition, physiognomy and ecology and shows varying relationships with other phytogeographic regions (Coetzee, 1978).

Because of the environmental similarity, the Sorensen's similarity coefficient proves that CCNP is more similar to that of "Bonga" and "Yayu" forests with a value of 53 and 52 (Table 4). This could be due to the fact that CCNP also located within the same ecological zone. The woody plant and the characteristics species identified in CCNP also have high similarity between Bonga and Yayu forests were described by the works of (Senbeta, 2006). 
Table 4. Comparison of CCNP Forest with other five forests in Ethiopia based on their similarities $(\mathrm{a}=$ common to CCNP afromontane type to the forest in comparison, $\mathrm{b}=$ found only in CCNP Forest, $\mathrm{c}=$ found only in the forest in comparison with CCNP, Sc = Sorensen's similarity coefficient, Ds = Dissimilarity).

\begin{tabular}{cccccc}
\hline Afromontane forest type & $\mathrm{a}$ & $\mathrm{b}$ & $\mathrm{c}$ & $\mathrm{Sc}$ & $\mathrm{Ds}$ \\
\hline Berhane-Kontir & 36 & 38 & 88 & 0.36 & 0.64 \\
Yayu & 43 & 31 & 47 & 0.52 & 0.48 \\
Harenna & 36 & 38 & 45 & 0.46 & 0.54 \\
Bonga & 46 & 28 & 54 & 0.53 & 0.47 \\
Maji & 37 & 37 & 27 & 0.46 & 0.46 \\
\hline
\end{tabular}

Source: W/Yohannes, 2006.

\subsection{Community Perception}

The residents located in and around CCNP areas are dependant almost exclusively on subsistence agriculture and livestock rearing. Informents from the society were asked wether park demarcation is important or not. All the the respondents agreed with the delineation of the park area. $72 \%$ of the respondents do not know well where the park boundaryis. $65 \%$ percent of the respondents do not agree with the present boundary. Roughly all of the respondents cited the shortage of pasture as their main challenge especially during dry season. $90 \%$ of the respondents complained that they are negatively influenced from wild animals either by crop riding or predation on the domestic animals and or threatening their lives. Human wildlife conflict is one of the main problems between the management of the park area and local communities (Datiko \& Bekele, 2013).

Strengthening the protected area system is an appropriate management tool for better conservation and use of the biological diversity of the study area.

The local community agrees that, the national park would benefited the local people by providing job opportunity through hiring scouts, and they hope that the park management could expand the infrastructure in the area to attract tourists so that the local people would have an opportunity to enhance their income through tourism.

\section{Conclusion and Recommendations}

\subsection{Conclusion}

A total of 106 species of woody plants belonging to 90 genera and 43 families were identified from the forest of CCNP. The families with the highest species richness were Fabaceae, followed by Rubiaceae, and Combrataceae. The study showed that the forest of CCNP contains high woody species diversity. The flora of CCNP is more similar to Bonga and Yayua fromontane forests of Ethiopia. The presence of rare wild animal species such as African Elephant (The flagship species for the study area), and six endemic plant species coupled with moist afromontane forest type, make the study area one of the best biodiversity hot 
spots as well as tourist destinations in the country.

Of all the environmental factors studied, disturbance and altitude determined the tree density and plant species richness in the study area. The main disturbances were caused by larger wild animals such as elephant and human caused disturbances, such as felling trees (deforestation). Crop riding or predation on the domestic animals and in some cases threatening human lives, are the main causes for human wild animals' conflict in the study area.

\subsection{Recommendations}

A practical strategy should be set in the management plan of the park to minimize the level of disturbances caused by wild animals and the surrounding people. HWC needs to be resolved wisely in such a way to benefit both the protected area management and the local community. Further ecological studies concerning the dynamics and composition of species in relation to environmental factors, ethno-botanical studies, the study on contribution of the forest to the economy of the local people, studies on indigenous knowledge of the local people on the use and management of forest and, the NTFPs in side CCNP has vital importance in the exploration of CCNP as well as to design a strategy to benefit the local people without harming the forest.

\section{Conflicts of Interest}

The authors declare no conflicts of interest regarding the publication of this paper.

\section{References}

Ademasu, M. (2006). History and Status of African Elephant Loxodonta africana, and Human-Elephant Conflict in Chebera Churchura National Park. M.Sc. Thesis, Addis Ababa: Addis Ababa University.

Alelign, A., Teketay, D., Yemshaw, Y., \& Edwards, S. (2007). Diversity and Status of Regeneration of Woody Plants on the Peninsula of Zegie, Northwestern Ethiopia. Tropical Ecology, 48, 37-49.

Alemu, S. (2011). Woody Species Composition, Diversity and Structural Analysis of Angada Forest in Merti Wereda, Arsi Zone of Oromia Region, Ethiopia (p. 102). Addis Ababa: Addis Ababa University.

Biru, Y., \& Bekele, A. (2012). Food Habits of African Elephant (Loxodonta africana) in Babile Elephant Sanctuary, Ethiopia.

Bongers, F., Popma, J., Castillo, M. D., \& Carabias, J. (1988). Structure and Floristic Composition of the Lowland Rain Forest of Los Tuxtlas, Mexico. Vegetatio, 74, 55-80. https://doi.org/10.1007/BF00045614

CCNP (2010). Annual Report.

Christine, B. S., Denich, M., Demissew, S., Ib Friis, \& Juergen, H. B. (2010). Floristic Diversity in Fragmented Afromontane Rainforests: Altitudinal Variation and Conservation Importance. Applied Vegetation Science, 13, 291-304.

Coetzee, J. A. (1978). Phytogeographical Aspects of the Montane Forests of the Chain of Mountains on the Eastern Side of Africa. Erdwiss Forsch, 11, 482-494. 
Datiko, D., \& Bekele, A.(2013). Conservation Challenge: Human-Carnivore Conflict in Chebera Churchura National Park, Ethiopia. Pakistan Journal of Biological Sciences, 16, 1758-1764. https://doi.org/10.3923/pjbs.2013.1758.1764

Environmental Protection Authority of Ethiopia (2011). GEF Portfolio Identification Document. Addis Ababa.

Friis, I. (1992). Forests and Forest Trees of Northeast Tropical Africa: Their Natural Habitats and Distribution Patterns in Ethiopia, Djibouti and Somalia.

Friis, I., Demissew, S., \& van Breugel, P. (2010). Atlas of the Potential Vegetation of Ethiopia. Denmark: Det Kongelige Danske Videnskabernes Selskab.

Gebre-Egziabher, T. B. (1991). Diversity of the Ethiopia Flora. In J. M. M. Engels, J. G. Hawkes, \& M. Worede (Eds.), Plant Genetic Resources of Ethiopia (pp. 75-81). Cambridge: Cambridge University Press.

Kent, M., \& Coker, P. (1992). Vegetation Description and Analysis: A Practical Approach (p. 351). London: Belhaven Press.

Kumar, A., Marcot, B. G., \& Saxena, A. (2006). Tree Species Diversity and Distribution Patterns in Tropical Forests of Garo Hills. Current Science, 91, 1370-1381.

Magurran, A. E. (2004). Measuring Biological Diversity. Hoboken, NJ: BlackWell.

Mengistu, K. (2002). Tropical Secondary Forest Management in Africa: Reality and Perspectives. Addis Ababa: FAO/EC.

Naveed, S., Hussain, F., Khattak, I., \& Badsha, L. (2012). Floristic Composition and Ecological Characteristics of Olea-Acacia Forest of Shamshokii District Karak. Global Journal of Science Frontier Research Biological Sciences, 12, 31-36.

Parker, K. C., \& Bendix, J. (1996). Landscape Scale Geomorphic Influences on Vegetation Patterns on Four Environments. Physical Geography, 17, 113-141.

Schmitt, C. B., Denich, M., Demissew, S., Friis, I. B., \& Boehmer, H. J. (2010). Floristic Diversity in Fragmented Afromontane Rainforests: Altitudinal Variation and Conservation Importance. Applied Vegetation Sciences, 13, 291-304.

Senbeta, F. W. (2006). Biodiversity and Ecology of Afromontane Rain-Forests with Wild Coffee Arabica L. Populations in Ethiopia. Ecology and Development Series No. 38, Bonn: Center for Development Research, University of Bonn.

Ssegawa, P., \& Nkuutu, D. N. (2006). Diversity of Vascular Plants on Ssese Island in Lake Victoria, Central Uganda. African Journey Ecology, 44, 22-29. https://doi.org/10.1111/j.1365-2028.2006.00609.x

The R Core Team (2012). A Language and Environment for Statistical Computing. Version 2.15.2, R Foundation for Statistical Computing.

W/Yohannes, D. (2006). Diversity, Distribution and Relative Abundance of the Avian Fauna of Chebera Churchura National Park, Ethiopia. MSC Thesis, Addis Ababa: Addis Ababa University.

Yeshitla, K., \& Bekele, T. (2002). Plant Community Analysis and Ecology of Afro-Montane and Transitional Rainforest Vegetation of Southwestern Ethiopia. SINET: Ethiopian Journal of Science, 25, 155-175.

Zewdie, A. (2007). Comparative Floristic Study on Menagesha Suba State Fores in the Years 1980 and 2006. MSc. Thesis, Addis Ababa: Addis Ababa University. 
Appendix. The List of Identified Woody Plant Species of the Study Area

1. Millettia ferruginea

2. Maesa lanceolata

3. Syzygium guineense

4. Vepris danelii

5. Croton macrostachyus

6. Macaranga capensis

7. Maytenus arbutifolia

8. Galiniera saxifrage (Diss)

9. Phoenix reclinata

10. Lepidotrichilia volkensi

11. Rothmannia urcelliformis (assefa AAU)

12. Terminalia brownie

13. Clerodenderum myriciodes

14. Vernonia ampla

15. Gardenia lutea

16. Combretum molle

17. Bersama abyssinica

18. Albizia gummifera

19. Polyscias fulva

20. Dracaena steudneri

21. Stereospermum kunthianum

22. Sapium ellipticum

23. Calpurina aurea

24. Albizia schimperiana

25. Cordia africana

26. Ficus vasta

27. Landolphia buchannaniin

28. Ficus sur

29. Vitex doniana

30. Terminalia laxiflora

31. Rytigynia neglecta

32. Celtis africana

33. Clausena anisata

34. Grewia molis

35. Coffee arabica

36. Ficus thoning

37. Sarcocephalus latifolius

38. Prunus africana

39. Brucea antidysentrica

40. Apodytes dimidiate

41. Bridelia scleroneura 
42. Dombeya torrida

43. Olea welwitschii

44. Piliostigma thonningii

45. Ekebergia capensis

46. Flacourtia indica

47. Enthada abyssinica

48. Dombeya Schimperiana

49. Nuxia congusta

50. Trema orientalis

51. Vangueria apiculata

52. Pterocarpus leucens

53. Ehretia cymosa

54. Aningeriaadolfi-friderici

55. Allophylus abyssinicus

56. Balanites aegyptiaca

57. Bridelia micrantha

58. Buddleia polystachya

59. Combretum Collinum

60. Combretum paniculatum

61. Erythriana abyssinica

62. Maytenus obscura

63. Oxyanthus speciosus

64. Teclea noblis

65. Vernonia amygdalina

66. Warburgia ugandensis

67. Trichilia emetic

68. Solanecio giggas

69. Senna Petersiana

70. Dobera glabra

71. Ozoroa insignis

72. Paullinia pinnata

73. Oncoba spinosa

74. Ilex mitis

75. Grewia flavescens

76. Gouania longipicata

77. Gnidia lamprantha

78. Embela schimperi

79. Dombeya kirkii

80. Dalbergia lacteal

81. Cusinia ostini

82. Baphyia abyssinica

83. Anogeissusleiocartar./leiocarpus

84. Ficus glumosa

85. Acacia seyal 
86. Acokanthera schimperi

87. Albizia grandibracteata

88. Carissaa edulis

89. Combutum adengonium

90. Cussonia holistic

91. Cussonia arborea

92. Dichrostachys cinerea

93. Rhus ruspoli

94. Schrebera alata

95. Sclerocarya birrea

96. Ficus exasperate

97. Hagenia abyssinica

98. Hippocratea africana

99. Lannea schimperi

100. Mimusops laurifolia

10. Rhamnus primoides

102. Tamarindus indica

103. Trichilia dregeana

104. Vernonia thomsoniana

105. Woodfordia uniflora

106. Embelia schimperi 